\title{
Distribution of the 21-Gene Breast Recurrence Score in Patients with Primary Breast Cancer in Germany
}

\author{
Verteilung des 21-Gen-Rezidiv-Scores bei Patientinnen \\ mit primärem Mammakarzinom in Deutschland
}

(c) (1) $\ominus$

\author{
Authors \\ Affiliations \\ 1 Department of Women's Health, University of Tübingen, \\ Tübingen, Germany \\ 2 Department of Obstetrics and Gynecology, University \\ of Heidelberg, Heidelberg, Germany
}

Vincent P. Walter ${ }^{1}$, Florin-Andrei Taran ${ }^{1}$, Markus Wallwiener ${ }^{2}$, Armin Bauer ${ }^{1}$, Eva-Maria Grischke ${ }^{1}$, Christina Barbara Walter ${ }^{1}$, Markus Hahn ${ }^{1}$, Sara Y. Brucker ${ }^{1}$, Andreas Daniel Hartkopf ${ }^{1}$

Key words

21-gene breast recurrence score, breast cancer, multigene assays, Oncotype DX

Schlüsselwörter

21-Gen-Rezidiv-Score, Mammakarzinom, Multigen-Assays, Oncotype DX

received 4.6.2019

revised 1.2.2020

accepted 2.2.2020

\section{Bibliography}

DOI https://doi.org/10.1055/a-1111-8734

Geburtsh Frauenheilk 2020; 80: 619-627 @ Georg Thieme

Verlag KG Stuttgart · New York | ISSN 0016-5751

Correspondence

Prof. Andreas Daniel Hartkopf

Department of Women's Health, University of Tuebingen

Calwerstraße 7, 72076 Tübingen, Germany

andreas.hartkopf@med.uni-tuebingen.de

\section{ABSTRACT}

Background Multigene assays are being used increasingly to aid in decision-making about chemotherapy in breast cancer. Here, we present the 21-gene recurrence score (RS) of patients tested in routine clinical practice in Germany.

Patients and Methods In a retrospective analysis, 4695 patients with hormone receptor-positive and HER2-negative early breast cancer ( $\mathrm{pT} 1-3, \mathrm{pN} 0-1, \mathrm{M} 0)$ were included in whom RS testing was conducted in Germany between No- vember 2015 and July 2018. RS groups as defined in the TAILORx trial (RS result 0-10; 11-25; 26-100) were used.

Results Of these patients, $21 \%$ were assigned to the low RS group, $63 \%$ to the midrange RS group, and 15\% to the high RS group. 1772 (81\%) of 2175 node-negative patients over 50 years of age were grouped either into the low RS group or the midrange RS group. The portion of patients with a low or midrange RS was $90 \%$ among node-positive patients (1284 of 1432 patients), $79 \%$ among patients with Ki-67-high ( $\geq 20 \%$ ) tumors (1829 of 2310 patients), $86 \%$ vs. $70 \%$ among patients with G2 and G3 tumors (3244 of 3762 patients and 368 of 522 patients), respectively, $88 \%$ among patients with a tumor size of $>5 \mathrm{~cm}$ (140 of 159 patients), and $82 \%$ among nodenegative patients at high clinical risk (1110 of 1352).

Conclusions The distribution of the 21-gene RS in German patients that were tested in routine clinical practice indicates that, according to the results of the TAILORx trial, chemotherapy may not be beneficial in most of these.

\section{ZUSAMMENFASSUNG}

Einleitung Multigen-Assays werden zunehmend als Entscheidungshilfe für eine Chemotherapie beim Mammakarzinom verwendet. Wir stellen hier den 21-Gen-Recurrence-Score (RS) von Patientinnen mit Brustkrebs vor, die routinemäßig in Deutschland untersucht wurden.

Patientinnen und Methoden 4695 Patientinnen mit hormonrezeptorpositivem und HER2-negativem Brustkrebs im Frühstadium (pT1-3, pN0-1, M0) wurden einer retrospektiven Analyse unterzogen. Bei diesen Patientinnen wurde in Deutschland zwischen November 2015 und Juli 2018 der Genexpressionstest Oncotype DX zur Ermittlung des RecurrenceScores durchgeführt. Die Klassifikation der RS-Gruppen erfolgte gemäß der TAILORx Studie (RS: 0-10; 11-25; 26-100). Ergebnisse Von diesen Patientinnen wurden $21 \%$ in die niedrige RS-Gruppe, $63 \%$ in die mittlere RS-Gruppe, und 15\% in die hohe RS-Gruppe eingeteilt. 1772 (81\%) von 2175 Patientinnen im Alter von über 50 Jahren und ohne Lymphknotenbefall wurden entweder in die niedrige oder die mittlere RS- 
Gruppe eingeteilt. Der Prozentsatz an Patientinnen mit einem niedrigen oder mittleren RS betrug $90 \%$ bei Patientinnen ohne Lymphknotenbefall (1284 von 1432 Patientinnen), 79\% bei Patientinnen mit einem hohen ( $\geq 20 \%)$ Ki-67-Wert (1829 von 2310 Patientinnen), $86 \%$ bzw. 70\% bei Patientinnen mit G2- bzw. G3-Tumoren (3244 von 3762 Patientinnen bzw. 368 von 522 Patientinnen), $88 \%$ bei Patientinnen mit einem Tumordurchmesser von $>5 \mathrm{~cm}$ (140 von 159 Patientinnen), und $82 \%$ bei Patientinnen ohne Lymphknotenbefall, aber mit einem hohen klinischen Risiko (1110 von 1352).

Ergebnisse Die Verteilung des 21-Gens RS bei deutschen Patientinnen, die in der klinischen Routinepraxis getestet wurden, deutet darauf hin, dass gemäß den Ergebnissen der TAILORx-Studie die Chemotherapie bei den meisten dieser Patientinnen keinen Nutzen hat.

\section{Abbreviations}

$\begin{array}{ll}\text { HER2 } & \text { human epidermal growth factor } 2 \\ \text { HR } & \text { hormone receptor } \\ \text { IQR } & \text { interquartile range } \\ \text { RS } & \text { 21-gene recurrence score }\end{array}$

\section{Key Message}

The 21 -gene breast recurrence score classified $83 \%$ of node-negative and $90 \%$ of node-positive patients tested in routine clinical practice in Germany as low or midrange RS.

\section{Introduction}

Breast cancer is the most common cancer and remains the number one cause of cancer-related deaths among women in the US [1] and Europe [2]. With advances in diagnostics and therapy, however, breast cancer mortality has improved remarkably over the last few decades [1]. Amid these developments, increasing efforts are being made to distinguish between patients who are likely to benefit from adjuvant chemotherapy and those who can be spared the toxic side effects while retaining their favorable prognosis $[3,4]$.

As weighing the advantages and disadvantages of chemotherapy is challenging, especially in hormone receptor (HR)-positive, human epidermal growth factor 2 (HER2)-negative patients [5], a number of multigene assays, such as the 21-gene Oncotype DX breast recurrence score (Oncotype DX $\left.{ }^{\circledR}, \mathrm{RS}\right)$ [6], the 70-gene signature $\left(\right.$ MammaPrint ${ }^{\circledR}$ ) [7], Endopredict ${ }^{\circledR}$ [8], and Prosigna ${ }^{\circledR}$ [9] are used in routine clinical practice to aid in decision-making.

The TAILORx trial was designed to prospectively validate the ability of the RS to estimate chemotherapy benefit in axillary lymph node negative HR+ HER2- patients [10]. Here, patients with a low RS $(\leq 10)$ were assigned to receive endocrine treatment alone and patients with a high RS $(\geq 26)$ were assigned to receive chemoendocrine treatment [10]. Patients with a midrange RS between 11-25 were randomized to receive either chemoendocrine treatment or endocrine treatment alone [10]. Initially published results show 9-year distant recurrence risks of 5, 8, 7 and $15 \%$ for the low RS, midrange RS + endocrine therapy, midrange RS + chemoendocrine therapy and high RS groups, respectively, and noninferiority of outcome in the midrange RS group not receiving chemotherapy on the basis of the RS result was postulated with some exceptions [11].
These exceptions were described in more detail in a secondary analysis recently published, where it was shown that clinical risk as defined in the MINDACT (Microarray in Node-Negative Disease May Avoid Chemotherapy) trial [12] (low clinical risk if primary tumor $\leq 3 \mathrm{~cm} \&$ low grade or $\leq 2 \mathrm{~cm}$ and intermediate grade or $\leq 1 \mathrm{~cm}$ and high grade) provided additional prognostic information in all RS groups [13]. Furthermore, patients $\leq 50$ years of age seemed to benefit from chemotherapy if their RS was 21-25 or if they were at high clinical risk with an RS of 16-20 [13].

Retrospective analyses of several prospective trials have suggested that the RS is prognostic and predictive of chemotherapy benefit also in node-positive patients [14-16]. According to the 2018 German S3 breast cancer guidelines, as well as the 2019 AGO breast cancer guidelines multigene assays may be used for patients with HR-positive HER2-negative, node-negative disease (in case of Oncotype DX, Prosigna and Endopredict) or in N0-N1 patients irrespective of hormone receptor and HER2 status (in case of MammaPrint), only if no clear decision regarding the use of adjuvant chemotherapy can be made based on conventional prognostic parameters $[17,18]$. The current NCCN guidelines strongly recommend considering the 21-gene assay in HR-positive node-negative patients with tumors $>0.5 \mathrm{~cm}$ in size and to consider multigene assays in HR-positive node-positive patients with $<4$ involved lymph nodes [19].

Here, we compare the RS result with clinical parameters in patients in Germany with primary invasive breast cancer for whom Oncotype DX testing was performed in routine clinical practice to aid in treatment decision-making.

\section{Methods}

\section{Patients and recurrence score}

This is a retrospective analysis of patients with HR-positive and HER2-negative early invasive breast cancer (pT1-3, pN0-1, M0) who received an Oncotype DX test in routine clinical practice between October 2015 and June 2017 in Germany. For this purpose, we obtained retrospective, anonymized data from Genomic Health Inc., Redwood City, USA. Grading and Ki-67 were evaluated by local pathologists and submitted to Genomic Health Inc. alongside the patients' lymph node status, tumor size and age. We could not obtain data about the treating entity or therapeutic regiment. After being comprehensively informed by their treating physicians, patients who underwent RS testing had to sign an Informed Consent Document providing detailed explications about the purposes and use of personal data comprising 
scientific research and related publications. The Informed Consent Document is regularly updated and complies with all applicable data protection laws, regulations and rules; in particular the EU-GDPR and the German Federal Data Protection Act. No ethics vote was required for analyzing the anonymized data according to the ethics commission of the University Hospital Tübingen, Germany.

\section{Statistical analysis}

We defined the low, midrange, and high RS groups in accordance with the definitions used for the TAILORx trial as an RS of $0-10$, $11-25$, and 26-100, respectively. Additionally, Ki-67 values of $<20 \%$ were defined as low and $\geq 20 \%$ as high [20]. For clinical risk, the definition used in the MINDACT trial [12] (low clinical risk if node-negative \& primary tumor $\leq 3 \mathrm{~cm} \&$ low grade or node-positive $\& \leq 2 \mathrm{~cm} \&$ low grade or node-negative $\& \leq 2 \mathrm{~cm}$ and intermediate grade or node-negative $\& \leq 1 \mathrm{~cm}$ and high grade) was deployed.

Correlations between categorical variables were assessed using Pearson's Chi-Squared Test. The significance level was set at $\alpha<0.05$. All tests were carried out as two-sided. Statistical analysis was performed using $\mathrm{R}$ version 3.5.0 and data visualization using the ggplot2 package version 3.1.0.

\section{Results}

\section{Patient characteristics}

Data from 4695 HR-positive, HER2-negative patients were available for analysis. The mean age was 56.6 years (standard deviation
10.4 years) with a median tumor size of $1.8 \mathrm{~cm}$ (interquartile range [IQR] $1.3-2.5 \mathrm{~cm}$ ) and a median Ki-67 of 20\% (IQR 10$25 \%)$, placing 2177 (49\%) into the low Ki-67 and 2310 (51\%) into the high Ki-67 group. In all, 3263 (69\%) patients had no lymph node involvement, while 1432 (31\%) were node positive. Furthermore, $283(6 \%), 3762(82 \%)$, and $522(11 \%)$ patients were graded as G1, G2, and G3, respectively and 1792 (40\%) were classified as low clinical risk. Compared with node-negative patients, the node-positive patients had a higher proportion of lower grade, Ki-67-low, clinically high-risk, and larger tumors, all $p<0.001$ $(\triangleright$ Table 1).

\section{Recurrence score}

The RS distribution can be seen in $>$ Fig. 1. The median RS was 16 (IQR 11-22), placing 1003 (21\%) patients into the low RS group, 2975 (63\%) into the midrange RS group, and 717 (15\%) into the high RS group. The distribution of clinicopathological patient characteristics by RS group is illustrated in $>$ Table 2 . Patients with high-grade tumors, Ki-67-high tumors, and node-negative patients were more likely to be in the high RS group (all $p<0.001$ ) whereas no association was seen for tumor size $(p=0.265)$ and clinical risk $(p=0.255)$ ( $\vee$ Table 2, Fig. 2 ). This was true both for patients older than 50 years and patients 50 years of age or younger. In the subgroups of node-negative and node-positive patients the same associations between clinicopathological features and RS result were observed as in the combined cohort ( $\bullet$ Fig. 3 ). In $55 \%$ of cases, Ki-67 and RS concordantly classified patients as low - low/midrange or high - high ( $>$ Fig.4); 1772 (81\%) of 2175 node-negative patients over 50 years of age were assigned a low or midrange RS. The proportion of patients with a low/midrange

- Table 1 Patient characteristics by axillary lymph node status.

\begin{tabular}{|c|c|c|c|c|c|}
\hline & & \multirow[b]{2}{*}{$\begin{array}{l}\text { All patients } \\
n\end{array}$} & \multicolumn{2}{|c|}{ Axillary lymph node } & \multirow[t]{2}{*}{$p\left(x^{2}\right)$} \\
\hline & & & $\begin{array}{l}\text { negative } \\
\text { n }\end{array}$ & $\begin{array}{l}\text { positive } \\
\text { n }\end{array}$ & \\
\hline \multicolumn{2}{|l|}{ All patients } & $4695(100)$ & $3263(100)$ & $1432(100)$ & \\
\hline \multirow[t]{3}{*}{ Grading } & G1 (\%) & $283(6)$ & $142(5)$ & $141(10)$ & \multirow[t]{3}{*}{$<0.001$} \\
\hline & G2 (\%) & $3762(82)$ & $2558(81)$ & $1204(84)$ & \\
\hline & G3 (\%) & $522(11)$ & $440(14)$ & $82(6)$ & \\
\hline \multirow[t]{2}{*}{ Ki-67 } & Low (\%) & $2177(49)$ & $1274(41)$ & $903(64)$ & \multirow[t]{2}{*}{$<0.001$} \\
\hline & High (\%) & $2310(51)$ & $1812(59)$ & $498(36)$ & \\
\hline \multirow[t]{3}{*}{ Tumor size } & $\leq 2 \mathrm{~cm}(\%)$ & $2644(59)$ & $1912(62)$ & $726(51)$ & \multirow[t]{3}{*}{$<0.001$} \\
\hline & $2-5 \mathrm{~cm}(\%)$ & $1703(38)$ & $1076(35)$ & $627(44)$ & \\
\hline & $>5 \mathrm{~cm}(\%)$ & $159(4)$ & $94(3)$ & $65(5)$ & \\
\hline \multirow[t]{2}{*}{ Age (years) } & $\leq 50(\%)$ & $1497(32)$ & $1087(33)$ & $410(29)$ & \multirow[t]{2}{*}{0.002} \\
\hline & $>50(\%)$ & $3197(68)$ & $2175(67)$ & $1022(71)$ & \\
\hline \multirow[t]{3}{*}{ RS group } & Low (\%) & $1003(21)$ & $641(20)$ & $362(25)$ & \multirow[t]{3}{*}{$<0.001$} \\
\hline & Midrange (\%) & $2975(63)$ & $2053(63)$ & $922(64)$ & \\
\hline & High (\%) & $717(15)$ & $569(17)$ & $148(10)$ & \\
\hline \multirow[t]{2}{*}{ Clinical risk } & Low (\%) & $1792(40)$ & $1712(56)$ & $80(6)$ & \multirow[t]{2}{*}{$<0.001$} \\
\hline & High (\%) & $2686(60)$ & $1352(44)$ & $1334(94)$ & \\
\hline
\end{tabular}




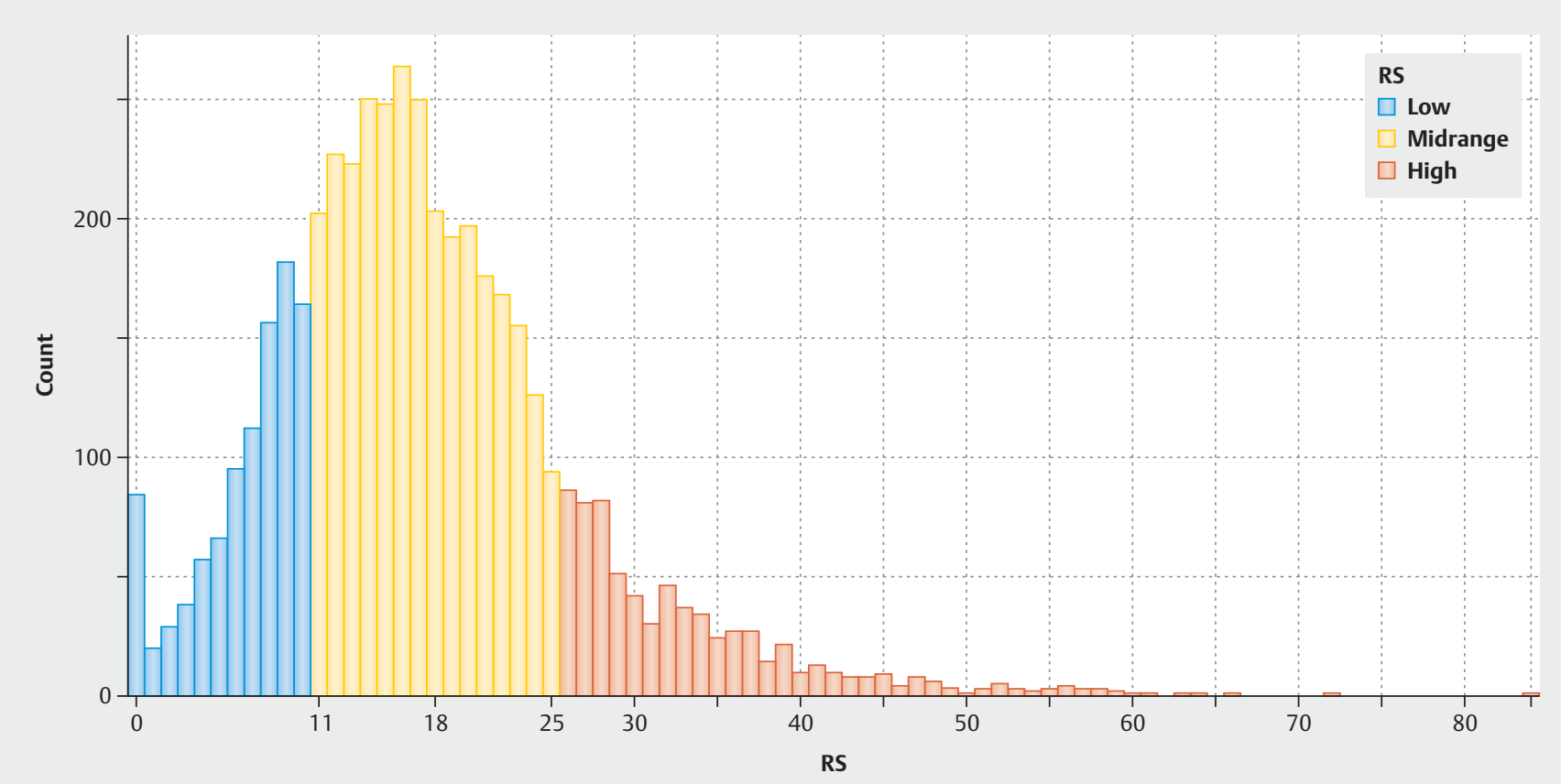

- Fig. 1 Distribution of RS in clinical routine in Germany.

- Table 2 Patient characteristics by RS group.

\begin{tabular}{|c|c|c|c|c|c|c|}
\hline & & \multirow[b]{2}{*}{$\begin{array}{l}\text { All patients } \\
n\end{array}$} & \multicolumn{3}{|l|}{ RS group } & \multirow[t]{2}{*}{$p\left(x^{2}\right)$} \\
\hline & & & $\begin{array}{l}\text { low } \\
\text { n (\%) }\end{array}$ & $\begin{array}{l}\text { midrange } \\
\mathrm{n}(\%)\end{array}$ & $\begin{array}{l}\text { high } \\
\text { n (\%) }\end{array}$ & \\
\hline \multicolumn{2}{|l|}{ All patients } & 4695 & $1003(21)$ & $2975(63)$ & $717(15)$ & \\
\hline \multirow[t]{2}{*}{ Nodal status } & negative & 3263 & $641(20)$ & $2053(63)$ & $569(17)$ & \multirow[t]{2}{*}{$<0.001$} \\
\hline & positive & 1432 & $362(25)$ & $922(64)$ & $148(10)$ & \\
\hline \multirow[t]{3}{*}{ Grading } & G1 & 283 & $86(30)$ & $181(64)$ & $16(6)$ & \multirow[t]{3}{*}{$<0.001$} \\
\hline & G2 & 3762 & $805(21)$ & $2439(65)$ & $518(14)$ & \\
\hline & G3 & 522 & $83(16)$ & $285(55)$ & $154(30)$ & \\
\hline \multirow[t]{2}{*}{ Ki-67 } & low & 2177 & $563(26)$ & $1413(65)$ & $201(9)$ & \multirow[t]{2}{*}{$<0.001$} \\
\hline & high & 2310 & $394(17)$ & $1435(62)$ & $481(21)$ & \\
\hline \multirow[t]{3}{*}{ Tumor size } & $<2 \mathrm{~cm}$ & 2644 & $549(21)$ & $1674(63)$ & $421(16)$ & \multirow[t]{3}{*}{0.265} \\
\hline & $2-5 \mathrm{~cm}$ & 1703 & $372(22)$ & $1095(64)$ & $236(14)$ & \\
\hline & $>5 \mathrm{~cm}$ & 159 & $38(24)$ & $102(64)$ & $19(12)$ & \\
\hline \multirow[t]{2}{*}{ Age (years) } & $\leq 50$ & 1497 & $275(18)$ & $1025(68)$ & $197(13)$ & \multirow[t]{2}{*}{$<0.001$} \\
\hline & $>50$ & 3197 & $728(23)$ & $1949(61)$ & $520(16)$ & \\
\hline \multirow[t]{2}{*}{ Clinical risk (N0) } & Low risk & 1712 & $338(20)$ & $1093(64)$ & $281(16)$ & \multirow[t]{2}{*}{0.526} \\
\hline & High risk & 1352 & $256(19)$ & $854(63)$ & $242(18)$ & \\
\hline \multirow[t]{2}{*}{ Clinical risk $(\mathrm{N}+)$} & Low risk & 80 & $29(36)$ & $47(59)$ & $4(5)$ & \multirow[t]{2}{*}{0.034} \\
\hline & High risk & 1334 & $329(25)$ & $863(65)$ & $142(11)$ & \\
\hline
\end{tabular}




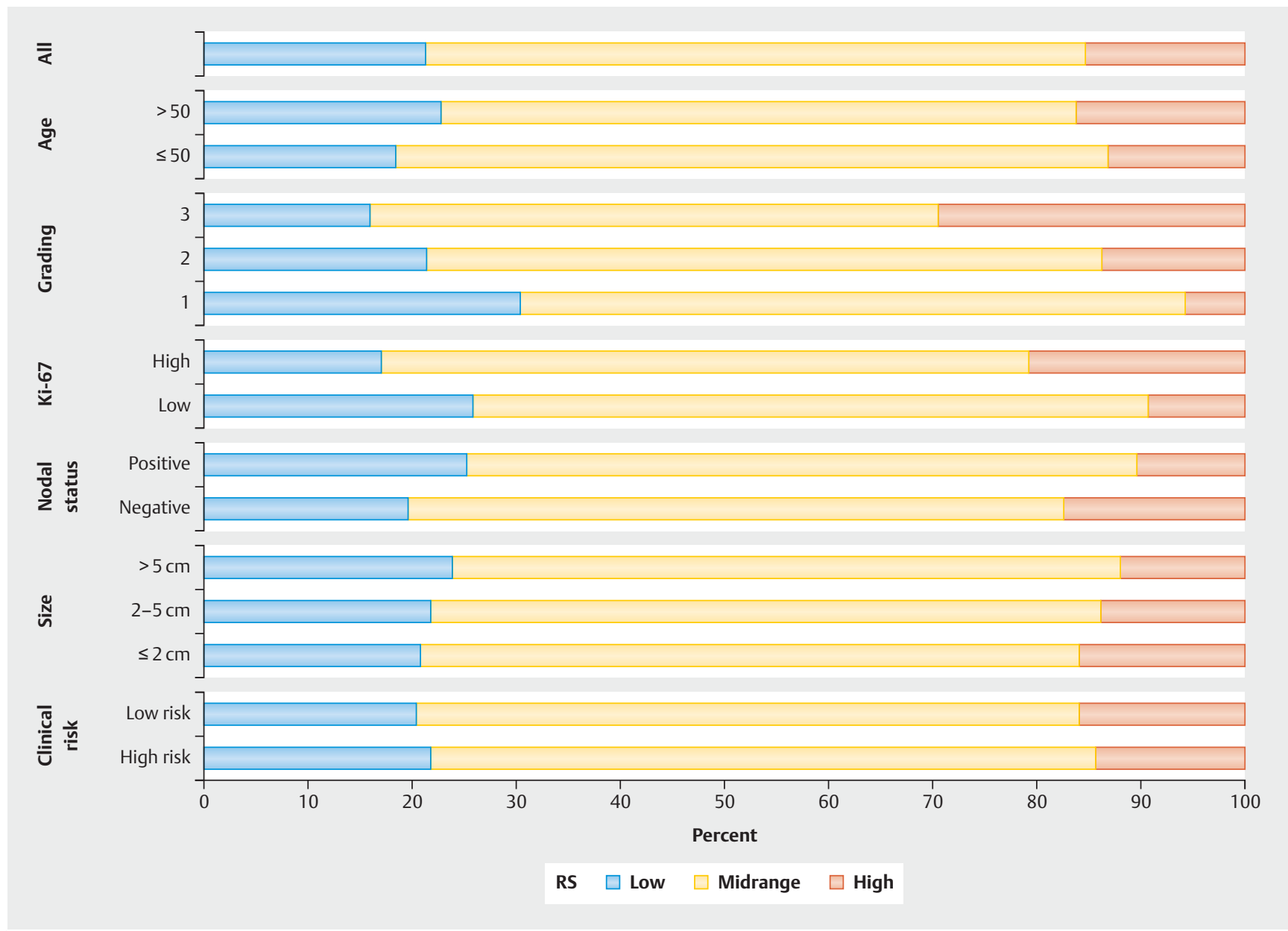

- Fig. 2 Distribution of RS groups by patient characteristics.

RS was $90 \%$ among node-positive patients (1284 of 1432 patients), 79\% among patients with Ki-67-high tumors (1829 of 2310 patients), $86 \%$ vs. $70 \%$ among patients with G2 and G3 tumors (3244 of 3762 patients and 368 of 522 patients), respectively, $88 \%$ among patients with a tumor size of $>5 \mathrm{~cm}$ (140 of 159 patients) and $82 \%$ of node-negative patients at high clinical risk (1110 of 1352).

\section{Discussion}

Using the RS in a large cohort of patients with HR-positive/HER2negative early breast cancer in Germany, we could identify according to the RS a large proportion of patients with clinically high-risk features such as high Ki-67 or high tumor grade, who according to the TAILORx results do not benefit from additional chemotherapy $[11,13]$.

The RS was initially developed as a prognostic tool, with scores of $<18$ defined as low risk, $18-30$ as intermediate risk, and $>30$ as high risk [6]. Using modified cut-off values the TAILORx trial demonstrated a lack of benefit from chemotherapy in the midrange RS group in a prospective randomized setting [11]. However, subgroup analyses revealed that women $\leq 50$ years of age with an RS of 21-25 regardless of clinical risk and women $\leq 50$ with an RS of 16-20 at high clinical risk may in fact derive a benefit from additional chemotherapy [13]. This benefit may likely be attributed to ovarian suppression caused by chemotherapy treatment [13] and should be investigated in future trials. Considering "prospective retrospective" data [21] from the National Surgical Adjuvant Breast and Bowel Project (NSABP) B20 [22] for chemotherapy benefit in patients with a low RS and TAILORx data [11,13] for midrange RS patients, women $>50$ years of age with an RS $\leq 25$ and women $\leq 50$ years of age with an RS $\leq 15$ regardless of clinical risk or $\leq 20$ at low clinical risk do not seem to benefit from chemotherapy in addition to endocrine therapy. In this cohort, 2397/ $3263(73 \%)$ of the node-negative patients were $>50$ years of age and had an RS $\leq 25$ or were $\leq 50$ and had an RS $\leq 15$ or were $\leq 50$, at low clinical risk and had an RS of $\leq 20$.

Retrospective data from prospective trials have been published indicating that node-positive patients with a low recurrence score may also not benefit from chemotherapy [14-16]. In the prospective Plan B study, clinically high-risk patients (including patients with 1-3 involved lymph nodes) with low RS $(\leq 11)$ had an excellent prognosis (94\% 5-year DFS), although chemotherapy benefit was not evaluated separately within the node-positive 


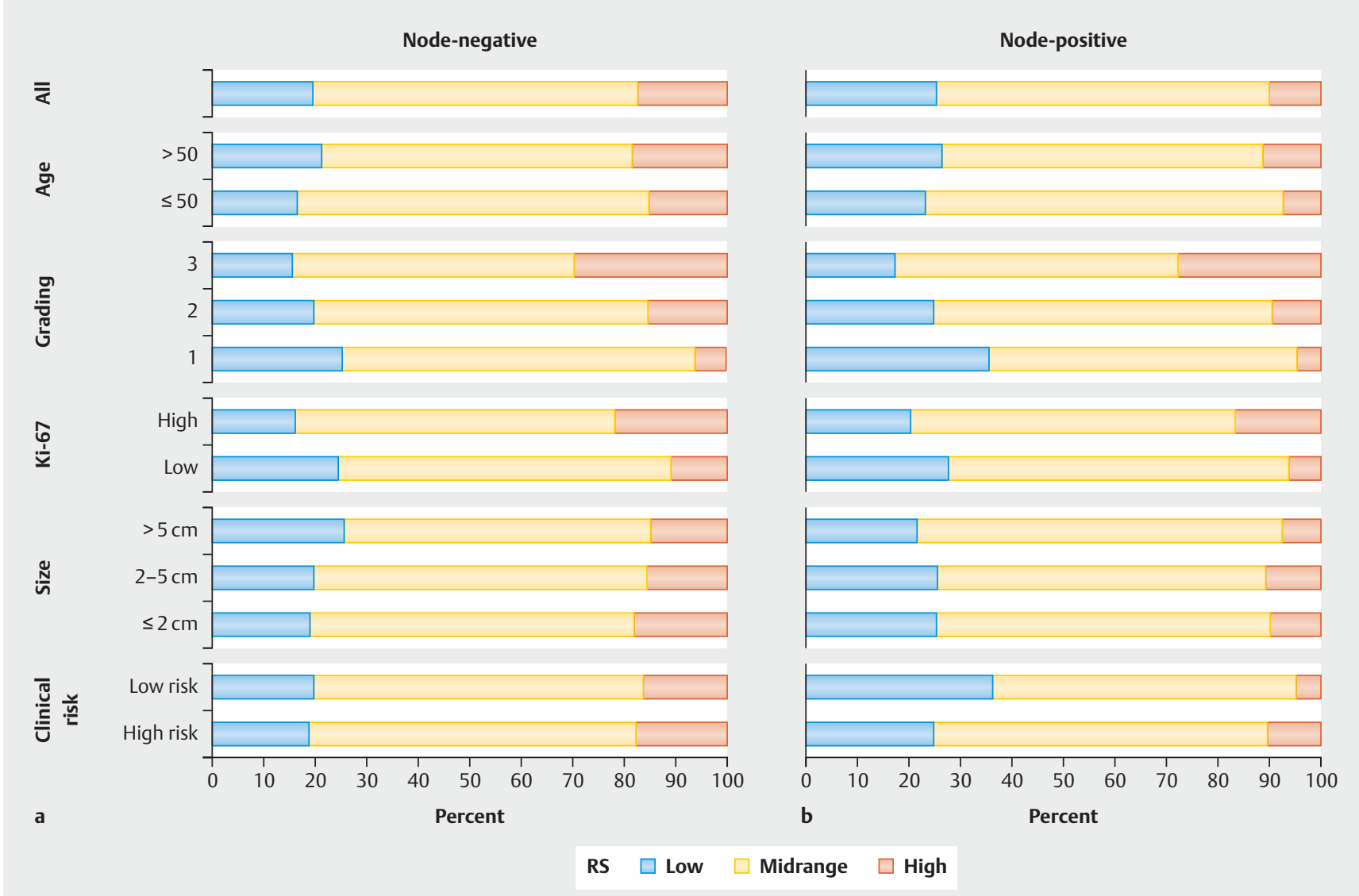

- Fig. 3 Distribution of RS groups by patient characteristics in node-negative patients (a) and node-positive patients (b).

subgroup [23]. Additionally, the MINDACT trial has prospectively shown that multigene assays can be of help in guiding therapy decisions regardless of node status [12]. There, 1404 node-positive patients were included and 912 (65\%) were classified as low genomic risk [12]. Of the 709 node-positive patients at high clinical and low genomic risk, 356 received no chemotherapy and no statistically significant difference was seen in distant metastasis free survival when compared with the 353 patients, who received chemotherapy [12]. Results from the RxPONDER study (NCT01272037), which aims to determine the clinical validity of OncotypeDX in node-positive patients, are currently pending. This prospective randomized trial is set to define cut-off values for the possible omission of chemotherapy in node-positive patients [24]. As these are not yet available, we used the TAILORx cutoff values of $0-10,11-25$, and $26-100$ for our entire cohort, which includes node-positive patients of whom $90 \%$ had an RS $\leq 25$.

$\mathrm{Ki}-67$ is used clinically to distinguish between luminal A- and Blike subtypes [20]. However, no clear cut-off values have been established; there is also high inter-observer variability and its role in predicting chemotherapy benefit remains unclear [25-27]. Using $20 \%$ as cut-off value, $49 \%$ of the patients in our cohort would have been classified as luminal A-like; however, $10 \%$ of these patients had a high RS, which is in line with earlier results [23]. Although we and others [28] found an association between Ki-67 and RS, the overall concordance rate of patients who would have received chemotherapy or not according to Ki-67 and RS results, respectively, was $55 \%$. What measure to base treatment decisions on, in such cases, where the RS and Ki-67 lead to different conclusions, is a question that has yet to be answered.

In retrospective analyses the RS has been shown to frequently disagree with other molecular tests [29] and in postmenopausal women in the TransATAC trial it was outperformed by other multigene assays as a prognostic tool, even after improving its performance substantially incorporating clinicopathological information in form of the RS-pathology-clinical assessment of distant recurrence risk (RSPC) [30]. However, the only two tests validated to estimate chemotherapy benefit (or rather the lack thereof) in large prospective trials are the 70-gene signature (MammaPrint) [12] and the RS [11, 13].

In the MINDACT trial, patients at low clinical but high genomic risk did not benefit from chemotherapy and patients at high clinical but low genomic risk may have [12]. With the RS, the predictive value in the low and high RS group remains unclear, as these patients were not randomly assigned to treatment groups in the TAILORx trial but treated uniformly [10]. Further research in this area is needed and it therefore remains important even in the age of multigene assays to always take clinical risk into consideration when decisions on treatment are made [31]. 


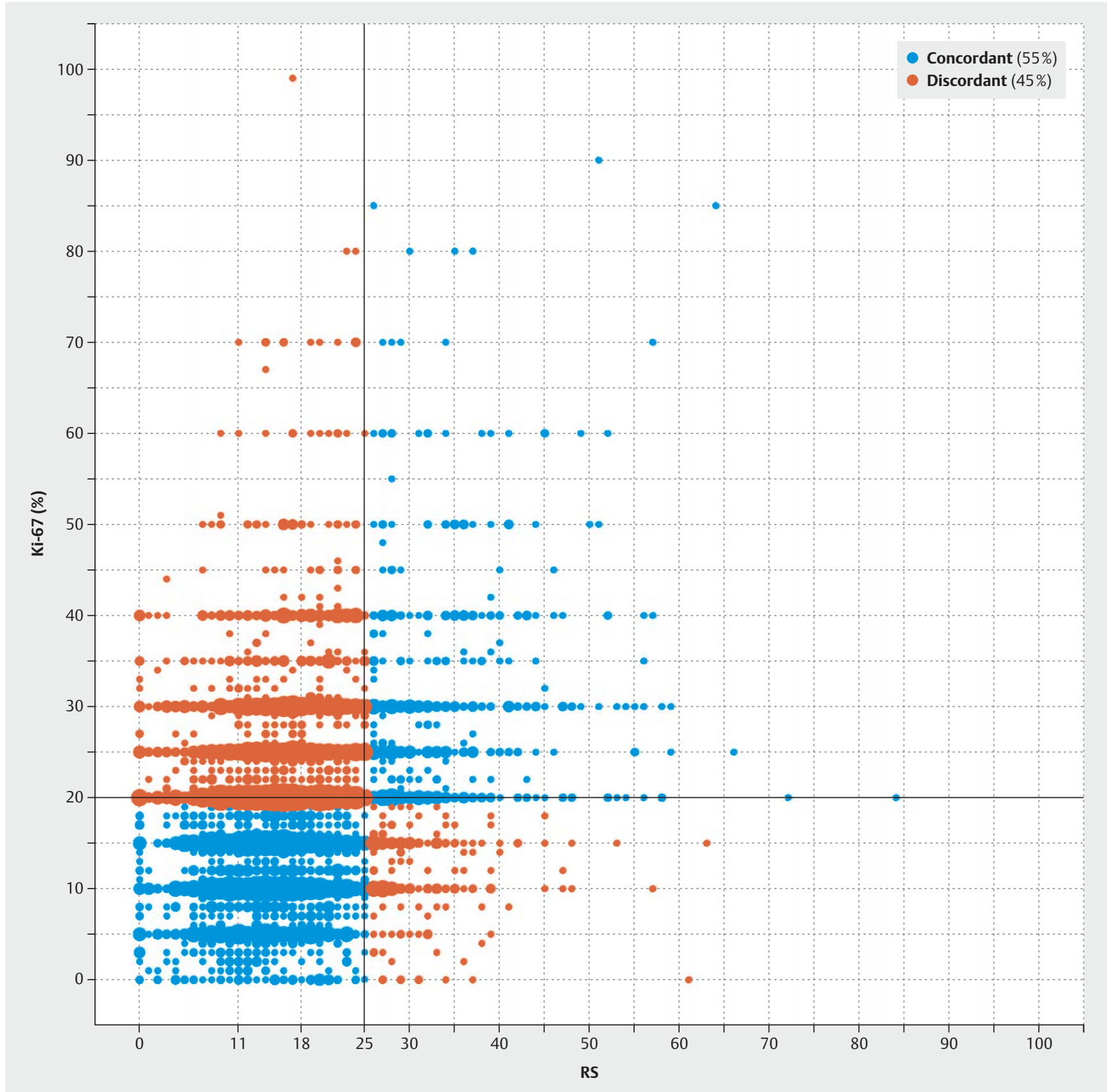

- Fig. 4 Comparison of Ki-67 staining and RS results. Dot size indicates number of observations. Here, 55\% were concordantly classified as high Ki-67 and high RS or low Ki-67 and low/midrange RS.

As a limitation of this study, the distribution of tumor characteristics is biased by the decision to use the RS and is therefore not representative for the whole population of HR-positive/HER2negative patients with early breast cancer. This is most likely why patients in whom axillary lymph nodes were involved more frequently had low-grade tumors and therefore had a higher rate of a low/midrange RS than node-negative patients. Just as observed in the Surveillance, Epidemiology, and End Results (SEER) database, node-positive patients in whom the RS was ordered tended to otherwise have low-risk clinical features when compared to their node-negative counterparts [32]. Bello et al. recently found that the RS distribution does not differ between node-negative and -positive tumors [33]. Additional limitations include the retrospective design of our study, the lack of treatment information and follow-up data, as well as the fact that no additional clinical risk factors such as menopausal status or progesterone receptor status were provided. We can therefore neither report patient outcome nor treatment efficacy. Furthermore, the records we received were incomplete with missing tumor size in 189 cases, $\mathrm{Ki}$ - 
67 in 208 cases, grading in 128 cases, and age in 1 case, which is why the clinical risk of 217 patients could not be classified.

\section{Conclusion}

In conclusion, the RS was performed in routine practice in both node-negative and node-positive patients. In a large fraction of node-negative patients it indicates that chemotherapy may not be beneficial based on TAILORx results $[11,13]$. In node-positive patients, its use was increased when other clinical factors, such as grading, Ki-67, or tumor size, indicated a lower clinical risk. Data from the prospective randomized RxPONDER-trial are awaited to evaluate whether patients with a low RS also might not benefit from chemotherapy and to determine the optimal RS cut-off values for decision-making.

\section{Funding}

No billing or payment was made by either party for the performance of this study.

\section{Conflict of Interest}

V.P.W. has been reimbursed for travel expenses by Genomic Health Inc. F.-A.T received consulting fees from Novartis, Tesaro, Genomic Health, Roche, Hexal, Astra Zeneca as well as a research grant from Genomic Health Inc.

S. Y. B. received a research grant from Genomic Health Inc. and speaker fees and honoraria from Pfizer, Roche, Novartis and AstraZeneca. A. D. H. received a research grant, speaker and consultancy honoraria from Genomic Health Inc. and speaker fees and honoraria from Pfizer, Roche, Novartis, Lilly, MSD and AstraZeneca, Tesaro, Colovis and Eisai. All remaining authors declare that they have no conflict of interest.

\section{References}

[1] Howlader N, Noone A, Krapcho M et al. SEER Cancer Statistics Review, 1975-2016, National Cancer Institute. 2019. Online: https://seer. cancer.gov/csr/1975_2016/; last access: 01.05.2019

[2] Ferlay J, Colombet M, Soerjomataram I et al. Cancer incidence and mortality patterns in Europe: Estimates for 40 countries and 25 major cancers in 2018. Eur J Cancer 2018; 103: 356-387

[3] Hartkopf A, Müller V, Wöckel A et al. Update Breast Cancer 2019 Part 1 Implementation of Study Results of Novel Study Designs in Clinical Practice in Patients with Early Breast Cancer. Geburtsh Frauenheilk 2019; 79: 256-267

[4] Untch M, Thomssen C, Bauerfeind I et al. Primary Therapy of Early Breast Cancer: Evidence, Controversies, Consensus: Spectrum of Opinion of German Specialists on the 16th St. Gallen International Breast Cancer Conference (Vienna 2019). Geburtsh Frauenheilk 2019; 79: 591-604

[5] Dowsett M, Goldhirsch A, Hayes DF et al. International Web-based consultation on priorities for translational breast cancer research. Breast Cancer Res 2007; 9: R81

[6] Paik S, Shak S, Tang G et al. A Multigene Assay to Predict Recurrence of Tamoxifen-Treated, Node-Negative Breast Cancer. N Engl J Med 2004; 351: 2817-2826

[7] van de Vijver MJ, He YD, van't Veer LJ et al. A Gene-Expression Signature as a Predictor of Survival in Breast Cancer. N Engl ] Med 2002; 347: 1999-2009
[8] Filipits M, Rudas M, Jakesz R et al. A New Molecular Predictor of Distant Recurrence in ER-Positive, HER2-Negative Breast Cancer Adds Independent Information to Conventional Clinical Risk Factors. Clin Cancer Res 2011; 17: 6012-6020

[9] Gnant M, Filipits M, Greil R et al.; on behalf of the Austrian Breast and Colorectal Cancer Study Group. Predicting distant recurrence in receptor-positive breast cancer patients with limited clinicopathological risk: using the PAM50 Risk of Recurrence score in 1478 postmenopausal patients of the ABCSG-8 trial treated with adjuvant endocrine therapy alone. Ann Oncol 2014; 25: 339-345

[10] Sparano JA, Paik S. Development of the 21-Gene Assay and Its Application in Clinical Practice and Clinical Trials. J Clin Oncol 2008; 26: 721-728

[11] Sparano JA, Gray RJ, Makower DF et al. Adjuvant Chemotherapy Guided by a 21-Gene Expression Assay in Breast Cancer. N Engl J Med 2018; 379 : $111-121$

[12] Cardoso F, van't Veer L], Bogaerts ] et al. 70-Gene Signature as an Aid to Treatment Decisions in Early-Stage Breast Cancer. N Engl J Med 2016; 375: 717-729

[13] Sparano JA, Gray RJ, Ravdin PM et al. Clinical and Genomic Risk to Guide the Use of Adjuvant Therapy for Breast Cancer. N Engl J Med 2019; 380: 2395-2405

[14] Albain KS, Barlow WE, Shak S et al. Prognostic and predictive value of the 21-gene recurrence score assay in postmenopausal women with nodepositive, oestrogen-receptor-positive breast cancer on chemotherapy: a retrospective analysis of a randomised trial. Lancet Oncol 2010; 11: 5565

[15] Dowsett M, Cuzick J, Wale C et al. Prediction of Risk of Distant Recurrence Using the 21-Gene Recurrence Score in Node-Negative and Node-Positive Postmenopausal Patients With Breast Cancer Treated With Anastrozole or Tamoxifen: A TransATAC Study. J Clin Oncol 2010; 28: 1829-1834

[16] Penault-Llorca F, Filleron T, Asselain B et al. The 21-gene Recurrence Score ${ }^{\circledR}$ assay predicts distant recurrence in lymph node-positive, hormone receptor-positive, breast cancer patients treated with adjuvant sequential epirubicin- and docetaxel-based or epirubicin-based chemotherapy (PACS-01 trial). BMC Cancer 2018; 18: 526

[17] Interdisziplinäre S3-Leitlinie für die Früherkennung, Diagnostik, Therapie und Nachsorge des Mammakarzinoms Langversion 4. 1 - September 2018. 2018. Online: http://www.leitlinienprogramm-onkologie.de/ leitlinien/mammakarzinom

[18] Janni W. Diagnostik und Therapie früher und fortgeschrittener Mammakarzinome. Online: https://www.ago-online.de/fileadmin/downloads/ leitlinien/mamma/2019-03/DE/Alle_aktuellen_Empfehlungen_2019. pdf; last access: 01.05.2019

[19] Goetz MP, Gradishar W], Anderson BO et al. NCCN Guidelines Insights: Breast Cancer, Version 3.2018. J Natl Compr Canc Netw 2019; 17: 118126

[20] Goldhirsch A, Winer EP, Coates AS et al. Personalizing the treatment of women with early breast cancer: highlights of the St Gallen International Expert Consensus on the Primary Therapy of Early Breast Cancer 2013. Ann Oncol 2013; 24: 2206-2223

[21] Simon RM, Paik S, Hayes DF. Use of Archived Specimens in Evaluation of Prognostic and Predictive Biomarkers. J Natl Cancer Inst 2009; 101: 1446-1452

[22] Paik S, Tang G, Shak S et al. Gene Expression and Benefit of Chemotherapy in Women With Node-Negative, Estrogen Receptor-Positive Breast Cancer. J Clin Oncol 2006; 24: 3726-3734

[23] Nitz U, Gluz O, Christgen M et al. Reducing chemotherapy use in clinically high-risk, genomically low-risk pN0 and pN1 early breast cancer patients: five-year data from the prospective, randomised phase 3 West German Study Group (WSG) PlanB trial. Breast Cancer Res Treat 2017; 165: 573-583 
[24] National Cancer Institute. Tamoxifen Citrate, Letrozole, Anastrozole, or Exemestane With or Without Chemotherapy in Treating Patients With Invasive Breast Cancer - RxPONDER. Online: https://clinicaltrials.gov/ct2/ show/NCT01272037; last access: 01.05.2019

[25] Dowsett M, Nielsen TO, A'Hern R et al. Assessment of Ki67 in Breast Cancer: Recommendations from the International Ki67 in Breast Cancer Working Group. J Natl Cancer Inst 2011; 103: 1656-1664

[26] Gluz O, Liedtke C, Huober J et al. Comparison of prognostic and predictive impact of genomic or central grade and immunohistochemical subtypes or IHC4 in HR+/HER2- early breast cancer: WSG-AGO EC-Doc Trial. Ann Oncol 2016; 27: 1035-1040

[27] Viale G, Regan MM, Mastropasqua MG et al.; on the behalf of the International Breast Cancer Study Group. Predictive Value of Tumor Ki-67 Expression in Two Randomized Trials of Adjuvant Chemoendocrine Therapy for Node-Negative Breast Cancer. J Natl Cancer Inst 2008; 100: 207-212

[28] Gluz O, Nitz UA, Christgen M et al. West German Study Group Phase III PlanB Trial: First Prospective Outcome Data for the 21-Gene Recurrence Score Assay and Concordance of Prognostic Markers by Central and Local Pathology Assessment. J Clin Oncol 2016; 34: 2341-2349
[29] Bartlett JMS, Bayani J, Marshall A et al.; on behalf of the OPTIMA TMG. Comparing Breast Cancer Multiparameter Tests in the OPTIMA Prelim Trial: No Test Is More Equal Than the Others. J Natl Cancer Inst 2016; 108

[30] Sestak I, Buus R, Cuzick J et al. Comparison of the Performance of 6 Prognostic Signatures for Estrogen Receptor-Positive Breast Cancer: A Secondary Analysis of a Randomized Clinical Trial. JAMA Oncol 2018; 4: 545

[31] Kolberg H-C, Schneeweiss A, Fehm TN et al. Update Breast Cancer 2019 Part 3 - Current Developments in Early Breast Cancer: Review and Critical Assessment by an International Expert Panel. Geburtsh Frauenheilk 2019; 79: 470-482

[32] Petkov VI, Miller DP, Howlader N et al. Breast-cancer-specific mortality in patients treated based on the 21-gene assay: a SEER population-based study. NPJ Breast Cancer 2016; 2: 16017

[33] Bello DM, Russell C, McCullough D et al. Lymph Node Status in Breast Cancer Does Not Predict Tumor Biology. Ann Surg Oncol 2018; 25: 2884-2889 